\title{
18F-labeled Mini-PEG Spacered RGD Dimer
}

National Cancer Institute

\section{Source}

National Cancer Institute. 18F-labeled Mini-PEG Spacered RGD Dimer. NCI Thesaurus.

Code C97334.

A radiotracer containing a pegylated dimeric Arg-Gly-Asp (RGD) peptide (NH2-mini-PEG$\mathrm{E}[\mathrm{C}(\mathrm{RGD} \mathrm{KK})] 2$ or $\mathrm{PRGD2}$ ) radiolabeled with fluorine 18F-fluorobenzoate (18F-FB), with potential alphaVbeta3 integ rin imaging activity upon positron emission topography (PET). Upon administration, the RGD moiety of 18F-labeled Mini-PEG Spacered RGD Dimer (18FFPRGD2) binds to alphaVbeta3 integrin. Upon PET, alphaVbeta3-expressing tumor cells can be visualized and the degree of tumor angiogenesis can be determined. This agent exhibits increased integ rin receptor binding affinity, tumor cell uptake and increased radiolabeling yield as compared to the non-pegylated form (18F-FRGD2). Integ rins, transmembrane glycoproteins, may be upregulated on proliferating tumor vessel endothelial cells and various cancer cells; their overexpression has been associated with neovascularization, differentiation, proliferation of tumor cells, metastasis and an overall poor prognosis. 